\title{
Efektivitas Program Pondok Pesantren Al-Qur'an Babussalam dalam Membina Masyarakat Muslim di Desa Ciburial
}

\author{
Diana Mujahidah* \\ Bandung, Indonesia. \\ *Dianamujahidah1303@gmail.com
}

Prodi Komunikasi Penyiaran Islam, Fakultas Dakwah, Universitas Islam

\begin{abstract}
Researchers focus on the effectiveness of Babussalam Islamic boarding school quranic program in fostering Muslim communities in Ciburial Village, the purpose of this research is to obtain data relatin to; (1) program planning, (2) program organization, (3) program evaluation, (4) effectiveness of theIslamic boarding school program Al-Qur'an Babussalam fostering the Ciburial village community. The Al-Qur'an Babussalam Islamic boarding school has an important role for the Ciburial village community, after a series of programs implemented by the Al-Qur'an Babussalam Islamic boarding school, this has brought people who are ordinary in understanding Islam now much more aware of Islamic teachings, both in implementation of worship, as well as in studying about Islamic teachings.
\end{abstract}

Keywords: Effectiveness, Program, Islamic Boarding School.

\begin{abstract}
Abstrak. Peneliti fokus kepada efektivitas program pesantren Al-Qur'an Babussalam dalam membina masyarakat muslim di Desa Ciburial, tujuan penelitian ini untuk memperoleh data yang berkenaan dengan; (1) perencanaan program, (2) pengorganisasian program, (3) pengevaluasian program, (4) efektivitas program pondok pesantren Al-Qur'an Babussalam dalam membina massyarakat desa Ciburial Pondok pesantren Al-Qur'an Babussalam memiliki peranan penting bagi masyarakat desa Ciburial, setelah rangkaian program yang dilaksanakan oleh pondok pesantren AlQur'an Babussalam, hal ini membawa masyarakat yang awam dalam pemahaman Islam kini jauh lebih banyak memahami ajaran Islam, baik dalam pelaksanaan ibadah, serta dalam menutut ilmu tentang ajaran Islam.
\end{abstract}

Kata Kunci: Efektivitas, Program, Pesantren 


\section{A. Pendahuluan}

Dakwah merupakan proses penyebaran Islam, hal ini sudah menjadi kewajiban setiap umat Muslim untuk melakukan dakwah. Sebagaimana perjuangan Rasul dan para sahabat dalam melakukan dakwahnya untuk menyebarkan ajaran Islam. Yang mana ajaran Islam ini merupakan suatu ajaran yang mengajak seluruh umatnya kepada jalan yang benar, yaitu jalan untuk menuju keridhoan Allah Swt.

Di tengah kehidupan masyarakat, sering kali dakwah diartikan hanya ulama yang disebut sebagai pendakwah menyampaikan pesannya di hadapan khalayak. Akhirnya dakwah dipahami sebagai tugas ulama semata; bentuk dakwah hanya sebagai ceramah agama; dan mitra dakwah selalu terdiri dari banyak orang. Pemahaman yang tidak tepat ini telah diterima oleh sebagian masyarakat secara umum, sehingga perlu dikemukan beberapa fenomena dakwah yang lain. Maka masyarakat bisa memahami dengan benar bahwa dakwah ini sebagai tugas setiap umat muslim tidak hanya kewenangan ulama saja.

Bagi seorang dai dalam menyebarkan ajarannya harus memliki strategi yang matang agar dakwahnya dapat diterima oleh masyarakat. Begitu banyak metode atau cara serta media yang bisa dimanfaatkan salah satunya dengan membangun pondok pesantren.

Pondok pesantren merupakan lembaga pendidikan Islam, tempat untuk menimba ilmu serta memperdalam ilmu pengetahuan ajaran Islam.

Pondok pesantren Al-Qur'an Babussalam merupakan salah satu lembaga pendidkan Islam yang berada di Desa Ciburial. Yang tujuannya untuk membina masyarakat di Kp. Babakan. Adapun inti permasalahan yang ditemukan bahwasanya, sebelum didirikannya pondok pesantren Al-Quran Babussalam warga di kp. Babakan mereka sudah memeluk agama Islam tetapi dalam pelaksanaan ibadah mereka masih kurang seperti; dalam membaca Al-Qur'an tanpa memahami isi kandungannya, aurat yang masih terbuka, banyaknya yang pernikahan dini hal ini dapat mengakibtkan kurangnya generasi muda dan rata-rata jenjang pendidikan mereka sampai SD karena untuk meneruskan ke jenjang berikutnya mereka harus menempuh jarak yang cukup jauh sehingga memerlukan biaya yang cukup banyak. Maka hal ini menjadi daya tarik peniliti untuk melakukan penelitian yang berkaitan tentang efektivitas program pondok pesantren Al-Qur'an Babussalam dalam membina masyarakat muslim di desa Ciburial. Berdasarkan uraian latar belakang masalah tersebut maka rumusan masalah:

1. Mengetahui perencanaan program Pondok Pesantren Al-Qur'an Babussalam dalam membina masyarakat muslim Desa Ciburial

2. Mengatahui pengorganisasian program Pondok Pesantren Al-Qur'an Babussalam dalam membina masyarakat muslim Desa Ciburial

3. Mengetahui evaluasi hasil program Pondok Pesantren Al-Qur'an Babussalam dalam membina masyarakat muslim Desa Ciburial

4. Mengetahui efektivitas program Pondok Pesantren Al-Qur'an Babussalam dalam membina masyarakat muslim Desa Ciburial

\section{B. Metodologi Penelitian}

Metode penelitian yang digunakan yaitu metode kualitatif deskriptif, penilitian kualitatif adalah untuk memberikan gambaran tentang suatu gejala atau hubungan antara hubungan gejala atau lebih. Dan penilitian kualitatif menghasilkan deskriptif berupa kata-kata yang meliputi data langsung yang didapatkan dari narasumber. Penelitian ini menggunakan penelitian deskriptif untuk memaparkan situasi dan peristiwa. Degan menggunakan metode ini dimaksudkan untuk menuturkan dan menafsirkan data mengenai respon masyarakat di Desa Ciburial terhadap program pondok pesantren Al-quran Babussalam. Dan alasan menggunakan metode ini adalah dapat memberikan gambaran secara logis dan sistematis.

Adapun objek dalam penelitian ini adalah pondok pesantren Al-Quran Babussalam serta yang menjadi subjek penelitian adalah warga kp. Babakan Desa Ciburial

Dalam teknik pengumpulan data peneliti melakukan wawancara, observasi, dokumentasi serta teknik analisi data yang bersifat kualitatif deskriptif. 


\section{Hasil Penelitian dan Pembahasan}

Pondok Pesantren Babussalam adalah pondok pesantren yang berlokasi di Desa Ciburial tepaatnya di Kp. Babakan Rt.01/Rw.01, yang didirikan pada 12 Rabiul Awal 1401 H bertepatan pada tanggal 8 Januari 1981. Pondok Pesantrean Al-Quran Babussalam ini di didirikan oleh KH. Drs. Muchtar Adam, beliau adalah seorang da'i yang memang sudah lama tinggal di Bandung.

Tujuan didirikannya Babussalam adalah untuk mewujudkan tempat pendidikan yang ber-intelektual, ber-spiritual,dan ber-akhlaqul karimah. Babussalam dibangun untuk membina kesadaran dan rasa tanggung jawab umat terhdap ajaranIslam melalui kesejahteraan dan lingkungan hidup, dalam rangka pembangunan manusia seituhnya. Pada akhirnya Babussalam dapat mewujudkan generasi Qur'ani yang unggul serta mengukuhkan syiar Islam, sekaligus mewaspadai gerakan kristenisasi yang pada saat itu sudah memasuki wilayah sekitar. Bersama para pengurus Babussalam generasi pertama dan penggeraka lahirnya Yayasan yang disahkan oleh Akte Notaris Koswara pada tanggal 6 Juli 1981, digagaslah pembentukan visi dan misi Yayasan sebgai berikut:

Visi : Pelopor dan Pusat pendidikan Al-Qur'an secara terpadu melalui lintas mazhab.

Misi : Menjadi salah satu wadah untuk mewujudkan Ukhuwwah Islamiyah dan Wahdatul Ummah dengan menggalang kerja sama berlandaskan kejujuran watak untuk berbhakti kepada agama, Nusa dan Negara Republik Indnesia.

Berdasarkan observasi penilitian terhadap pondok pesantren Al-Qur'an Babussalam menurut peniliti hal ini sudah cukup baik dalam perkembangannya, dalam menyebar luaskan agama Islam, serta dalam membina masyarakat di kampung Babakan sudah dinilai cukup baik, hal ini dapat dilihat dengan banyaknya kemajuan di Daerah Ciburial khususnya di Kampung Babakan para warganya yang sudah banyak sekali kemajuan dalam pemahaman agama Islam, hal ini disebabkan karena pondok pesantren Al-Qur'an Babussalam memiliki misi yaitu pondok pesantren Al-Qur'an Babussalam dapat menjadi salah satu wadah ukhuwah Islamiyah dan Wadhatul Ummah dengan menggalang kerjasama berlandaskan kejujuran watak untuk berbakti kepada agama, nusa dan negara Republik Indonesia dan didirikannya pondok pesantren AlQur'an Babussalam memilki tujuan utama yaitu mewujudkan tempat pendidikan yang berintelektual, ber-spiritual dan ber-akhlaqul karimah, serta untuk membina kesadaran dan tanggung jawab masyarakat terhadap ajaran Islam, menciptkan generasi Qur'ani yang unggul sehingga mereka dapat mengamalkan ajaran Islam secara luas. Hal ini sesuai dengan teori yang dikemukakan oleh Mohamad Takdir dalam bukunya yang berjudul Modernisasi Kurikulum Pesantren bahwa pesantren merupakan tempat belajar ilmu agama yang saling berpengaruh dalam membetuk karakter dan kepribadian umat.

\section{Perencanaan Program Pondok Pesantren Al-Qur'an Babussalam}

Perencanaan program pondok pesantren Al-Qur'an Babussalam terdiri dari:

a. Bidang pendidikan

Dengan adanya program pendidikan dapat membantu masyarakat untuk melanjutkan sekolahnya ke jenjang yang lebih tinggi. Adapun pendidikan di pondok pesantren Al-Qur'an Babussalam ini terdiri dari; sekolah TK-SD-SMP-SMA. Dengan penerapan kurikulum pesantren terpadu untuk semua jenjang pendidikan.

b. Bidang Dakwah

Program dakwah bertujuan untuk meningkatkan kualitas dakwah denga menyebarkan secara luas tentang ajaran Islam, seperti dengan mengadakan korp mubaligh hijrah yang dilakukan oleh para siswa dengan terjun langsung ke masyarakat dalam berdakwah.

c. Bidang sosial

Bidang sosial ini bertujuan untuk membantu para warga yang kekurangan dalam segi ekonomi, sehingga mereka sangat perlu dibantu, memang dalam kebutuhan rumah sudah tercukupi tetapi untuk kebutuhan sekolah mereka kekurangan seperti; membeli buku, membeli kuota internet, seragam, dan biaya sekolah lainya, maka perlu kita bantu, dan status mereka itu yatim piatu, atau orang tua mereka sudah bercerai. Babussalam berharap anak-anak didik mereka belajar dengan tenang karena kebutuhan nya tercukupi. 
d. Bidang usaha

Bidang usaha tujuannya untuk peningkatan kemampuan kapasitas percetakan, mengoptimalkan pemasaran wisata rohani, melakukan rekrutman dan peningkatan kualitas SDM, pengoptimalkan pengelolaan pengobatan suntik lebah, herba, thibbun nabawi (pengobatan nabi).

e. Bidang Baitul Maal

Bidang baitul maal melakukan pemetaan kekuatan dan menggali potensi umat dalam melaksanakan kewajiban mengeluarkan zakat, infak dan sodakah yang disalurkan melalui Badan Amil Zakat serta mengembangkan system penarikan dana dari umat sehingga lebih berhasil guna dan terkoordinasi dengan baik.

f. Bidang Administrasi dan personalia

Bidang administrasi dan personalia melakukan penyempurnaan sistem administrasi di lingkungan Babussalam, Peningkatan SDM melalui kursus manajemen perkantoran, meningkatkan pembinaan organisasi dan pengelolaan Yayasan Babussalam Cabang dalam aspek manajemen perkantoran dan keuangan, serta penyempurnaan pola karir dan sistim Penggajian .

g. Unit Umrah dan Haji

Dalam bidang Umrah dan Haji pondok Pesantren Al-Qur'an Babussalam dapat memberangkatkan masyarakat di Desa Ciburial yang berkeinginan untuk pergi haji atau umrah karena pada saat belum adanya pondok Pesantren Al-Qur'an Babussalam jemaah haji di desa Ciburial hanya sedikit sehingga kurangnya penggerak dalam membimbing untuk melaksanakan ibadah Haji dan Umrah namun setelah di buatnya program tersebut jemaah haji kian bertambah di Desa Ciburial sehingga dapat membantu kemajuan Pondok Pesantren Al-Qur'an Babussalam. Semakin bertambah nya jemaah haji yang ikut maka ikut membantu bagi guru dan staf yayasan Babussalam untuk memberangkatkan mereka pergi Haji dan Umrah. Perencanaan program Haji dan Umrah diantaranya:

Berdasarkan uraian hasil penilitian yang ditemukan dalam proses perencanaan yang dilakukan oleh Pondok Pesantren Al-Quran Babussalam dalam membina masyarakat menurut peneliti hal ini sudah cukup baik karena dapat terlihat dari perencanaan yang sudah mereka lakukan karena rencana yang mereka lakukan dapat memberikan manfaat kepada masyarakat sekitar, tersusun dengan baik, setiap program memiliki strategi rencana yang tersistematis agar bisa teraplikasikan ke masayarakat. Hal ini sesuai dengan teori perencanaan, yang dikemukakan oleh Gorden B. Dafis dalam bukunya kerangka dasar sistem informasi manajemen perencanaan merupakan suatu arah tindakan yang sudah ditentukan terlebih dahulu, perencanaan ini akan mengungkapkan tujuan-tujuan keorganisasian dan kegiatan-kegiatan yang diperlukan guna mencapai tujuan.

\section{Pengorganisasian program pondok pesantren Al-Qur'an Babussalam}

Demi terlaksananya suatu perencanaan program maka pondok Pesantren Al-Qur'an Babussalam membuat pengelompokan dengan membuat sruktur perorganisasian sebagai berikut:

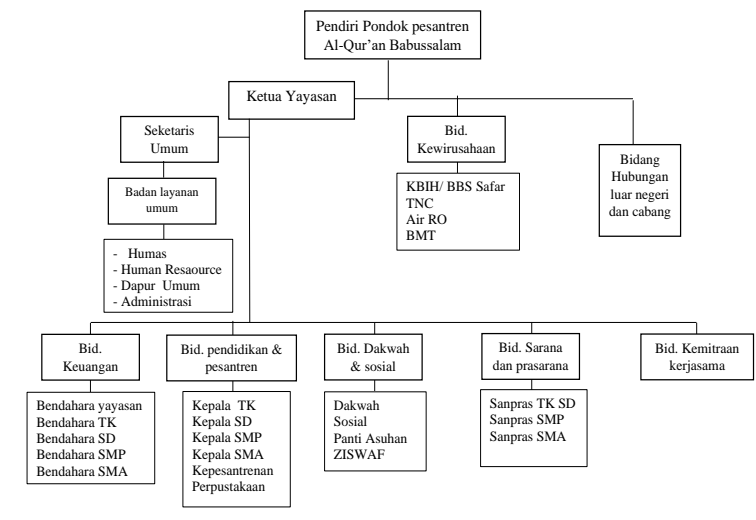

JRKPI is licensed under Creative Commons Attribution-

NonCommercial-ShareAlike 4.0 International License. Komunikasi Penyiaran Islam 


\section{Gambar 1.}

Berdasarkan observasi penilitian yang sudah dilakukan terhadap pengorganisasian yang dilakakukan oleh Pondok pesantren Al-Qur'an Babussalam dalam mewujudkan program yang sudah direncanakan menurut peniliti hal ini sudah efektiv dilakukan, karena dapat terlihat dari perkembangan serta kemajuan terlaksananya suatu program, hal ini dikarenakan mereka dalam pengorganisasiannya tersusun atas struktur yang mereka sudah lakukan sejak dahulu yaitu dengan membuat pengelompokan yang terdiri dari tingkat pengurus yayasan, tingkat bidang dan tingkat unit. Hal ini sesuai dengan teori pengorganisasian yang dikemukakan oleh M. Munir, dan Wahyu Illahi dalam bukunya yang berjudul manajemen dakwah, pengorganisasian yaitu proses pengelompokan orang-orang, serta memberikan tugas dan wewenang yang sedemikian rupa demi terwujudnya suatu tujuan.

\section{Pengevaluaisian Program Pondok Pesantren Al-Qur'an Babussalam}

Dalam proses pengevaluasian program yang dilakukan oleh pondok pesantren Al-Qur'an Babussalam mereka membuat sistematika yatu dimulai dari tingkat unit, tingkat bidang dan tingkat pengurus Yayasan. Adapun permasalahan yang mereka hadapi adalah tentang permasalahan dana serta SDM.

Berdasarkan observasi penelitian yang ditemukan dalam proses pengevaluasian program pondok pesantren Al Qur'an Babussalam menurut peniliti hal ini sudah efektiv dilakukan, terbukti denga banyaknya kemajuan serta perkembangan masyarakat di desa ciburial khusus nya di kampung Babakan, banyaknya program sudah terlaksana dengan baik, dan kerja sama antar anggota dilakukan dengan baik seperti pemimpin dalam memimbing para pegawainya untuk berusaha bekerja keras dengan menyesuaikan kemampuan mereka hal ini juga sudah dilakukan dengan sangat baik, dengan menjalin komunikasi satu lain sehinga setiap program yang direncanakan dan dilaksanakan terealisasikan sesuai dengan yang mereka harapkan. Maka proses pengevaluasian yang mereka lakukan sudah terlaksana dengan baik, hal ini dikarenakan mereka memiliki sistematika dalam melakukan pengevaluasian yaitu mengadakan rapat tingkat unit, tingkat bidang setelah itu tingkat pengurusan, hal ini dilakukan agar mereka dapat berkomnukasi dengan baik, Sehingga tidak adanya konflik atau kesalah pahaman dan yang menjadi titik kumpul dalam melakukan evaluasi ini adalah bersama para pengurus yayasan tentunya dengan menghadirkan para unit serta bidang, yang mereka adakan pada akhir tahun.

Mereka menjabarkan setiap program-program yang mereka rencanakan, menganai target, hambatan serta solusi dan menyimpulkan hasil program yang sudah terlaksana atau belum maksimal. Tentunya setiap bidang memiliki kendala nya masing-masing sehingga mereka bekerja sama dalam memberikan solusi. Serta memberikan dorongan kepada satu sama lain agar mereka terus meningkatkan kerja sama tidak hanya pengurus yayasan dan para bidang, unit lainnya melainkan bekerja sama dan mejaga silaturahim kepada lembaga yang lain, hal ini dilakukan dalam mewujudkan terlaksananya program-program Pondok Pesantren Al Quran Babussalam.

Hal ini sesuai dengan teori evaluasi yang dibawakan oleh Corn Bach evaluasi yang baik adalah evaluasi yang memberikan dampak positif pada perkembangan pelaksanaan suatu program misalnya dalam evaluasi prestasi kerja karyawan dan evaluasi adalah penilaian pada proses akhir terlaksananya suatu pekerjaan dan hasil kerja tersebut Sudahkah selesai dan sesuai dengan tujuan. Seberapa jauh para anggota melakukan tanggung jawabnya dan memberikan pertimbangan dalam memberikan tugas selanjutnya.

\section{Efektivitas program pondok pesantren Al-Qur'an Babussalam}

Berdasarkan observasi penelitian yang ditemukan dalam efektivitas program pondok pesantren Al Qur'an Babussalam membina masyarakat muslim di Desa Ciburial khusus nya di kampung Babakan menurut peniliti sudah cukup efektiv dan berjalan dengan baik. Karena setiap program yang sudah direnacakan terlaksana dengan baik, terorganisir dengan baik serta sering mengadakan evaluasi yang sangat baik, Sehingga program yang dilakukan memberikan 
kemajuan terhadap masyarakat, berikut adalah perkembangan yang terjadi di lingkungan masyarakat;

a. Pelaksanaan ibadah

Berdasarkan observasi peniltian yang ditemukan menurut peniliti dalam pelaksanaan ibadah mereka mereka semakin meningkat yaitu dalam pelaksnaan sholat 5 waktu yang kini semakin rutin dan takut untuk ditinggalkan, bahkan tidak hanya sholat wajib saja yang mereka kerjakan tetapi juga mereka mengerjakan ibadah Sunnah lainya, seperti sholat dhuha, sholat tahajjud, sholat rawatib ba'da maupun qobla, dan sholat sunnah lainnya. Hal ini dikarenakan banyaknya program pemahaman Islam terhadap masyarakatnya itu sendiri. Namun tidak banyak juga yang jarang mengerjakan dikarenakan mereka jarang mengikuti kegiatan di pondok pesantren Al-Qur'an Babussalam. Menurut peniliti pondok pesantren Al-Qur'an Babussalam sudah berhasil mengajak masyarakatnya untuk menyempurnakan ibadahnya.

b. Pemahaman baca Al-Qur'an

Berdasarkan observasi peniltian yang ditemukan menurut peniliti masyarakat desa Ciburial khususnya di kampung Babakan kini sudah meningkat, hal ini terbukti dari banyaknya alumni yang ikut membantu dalam mengajarkan dalam membaca Al-Qur'an. Sehingga banyanyak penghafal Al-Qur'an yang mendapat beasiswa ke perguruan tinggi serta yang ikut mengajar para generasi selanjutnya dalam menghafal dan membaca Al-Qur'an. Namun masih ada beberapa yang tidak membaca Al-Qur'an karena mereka jarang mengikuti kegiatan kajian di Babussalam. Menurut peniliti setelah melihat banyaknya kemajuan dari masayarakat berkenaan dalam pemahaman membaca Al-Qur'an hal ini sudah cukup berhasil.

\section{c. Berbusana muslim}

Berdasarkan observasi peniltian yang ditemukan menurut peniliti dalam berbusana muslim mereka banyak sekali perubahan di bandingkan tahun yang lalu, kini rata-rata masyarakat di Babakan Desa Ciburial para kaum wanitanya sudah mengenakan hijab, serta di masing-masing rumah kini sudah memiliki jamban sehingga pada saat mereka mandi tidak terlihat oleh yang bukan mahramnya, karena kini pemikiran mereka sudah memahami mengenai hukum aurat. Hal ini tentunya dengan ada pondok pesantren Babussalam yang memberikan pemahaman kepada masyarakatnya serta program-program yang terus mereka lakukan sampai sekarang, menurut peniliti setelah melihat banyaknya kemajuan dari masayarakat berkenaan dalam pemahaman membaca Al-Qur'an hal ini sudah cukup berhasil.

d. Pernikah dini

Berdasarkan observasi peniltian yang ditemukan menurut peniliti pernikihan dini sudah berkurang karena pemahaman masyarakat sudah terbuka dan mengetahui pentinggnya bahwa menikah itu harus memiliki pengetahuan, bagi perempuan agar bisa mendidik anak-anak nya dan bagi kaum laki-laki bisa menjadi seorang imam yang baik dalam memimpin keluarganya, dengan bekal ilmu pengetahuan dapat menunjang perekonomian keluarganya untuk bisa hidup lebih baik.

\section{e. Pendidikan}

Berdasarkan observasi peniltian yang ditemukan menurut peniliti penidikan di kampung Babakan sudah banyak peningkatatan seperti meningkatnya para lulusan sarjana dibanding tahun sebelumnya, berkurangnya pernikahan dini, berkurangnya pengangguran serta meningkat generasi muda yang mampu meneruskan dalam menyebarkan ilmu pengetahuan khususnya ajaran tentang Islam. menurut peniliti setelah melihat banyaknya kemajuan dari masayarakat berkenaan dalam pemahaman membaca Al-Qur'an hal ini sudah cukup berhasil.

Maka dari uraian hasil penelitian tersebut menurut peneliti dalam program pondok pesantren Al-Qur'an Babussalam dalam mebina masyarakat muslim di desa Ciburial sudah efektiv karena sudah mencapai tujuan yang mereka harapkan, maka ini sesuai dengan teori efektivitas yang dikemukakan oleh Aswar Annas dalam bukunya yang berjudul Interakasi Pengambilan Keputusan Dan Evaluasi Kebijakan bahwa efektivitas yaitu tingkat pencapaian tujuan atau sasaran organisasional sesuai yang telah ditetapkan, dan dapat di katakan efektif apabila sesuatu pekerjaan dapat dilakuan dengan baik sesuai dengan yang direncanakan, maka dapat dikatakan efektiv dengan mengukur efektivitas suatu program dapat menilai keberhsilan dari program tersebut dalam mencapai tujuannya.

JRKPI is licensed under Creative Commons Attribution-

NonCommercial-ShareAlike 4.0 International License. Komunikasi Penyiaran Islam 


\section{Kesimpulan}

Berdasarkan skripsi yang telah dijelaskan sebelumnya, maka skripsi ini dapat disimpulkan sebagai berikut:

1. Pondok pesantren Al-Quran Babussalam telah melakukan proses perencanaan dengan efektif baik untuk bidang Pendidkan, bidang dakwah, bidang sosial, bidang usaha, bidang Baitul Maal, Bidang administarasi hal itu dinilai dengan melihat banyakanya perkembangan serta kemajuan yang terjadi di Masyarakat.

2. Pondok pesantren Al-Quran Babussalam telah melakukan proses pengorganisasian dengan efektif karena hal ini dapat di nilai dengan mambangun kinerja yang baik yang telah mereka lakukan dalam tanggung jawab atas setiap tugas yang diberikan sehingga kita dapat melihat perkembangan serta kemajuan masyarakat dengan adanya pondok pesantren Babussalam.

3. Dalam melakukan proses pengevaluasi pondok pesantren Babussalam sudah efektif hal ini dapat di nilai dari pembaharuanya setiap program serta cara mereka menangani dari setiap hambatan yang terjadi sehingga mengahasilkan kemajuan bagi Pondok pesantren Babussalam.

4. Efektifitas program Pondok pesantren Al-Quran Babussalam sudah cukup efektif, hal ini dapat dilihat dari kemajuan masyarakatnya tentang pemahaman Islam, baik dalam ibadah sholatnya sudah rutin dijalankan, bagi kaum wanita kita sudah banyak yang memakai jilbab, pendidikan lkini meningkat tidak ada lagi yang putus sekolah dan kini bertambahnya para sarjana yang alumni

\section{Daftar Pustaka}

[1] Ahmad Warson, M. (1997). Kamus Al-Munawwir. Surabaya: Pustka Progresif.

[2] Al-Bayanuniy, S. M.-F. (2010). Al-Madkhal Ila Ilmi Ad-Dakwah. In D. Junaedi, Ilmu Dakwah Prinsip dan Kode Etik Berdakwah Menurut Al-Qur'an dan As-Sunnah. Jakarta: AKADEMIKA PRESSINDO.

[3] Anwar, M. \&. (2018). Filosofi Dakwah Kontemporer. Riau: PT. Indragiri Dot Com.

[4] AS, E. (2009). Dasar-dasar Ilmu Dakwah. Widya Padjadjaran.

[5] Dafis, G. B. (1984). Kerangka Dasar Sistem Informasi Manajemen. Jakarta: PT. Pustaka Binaman Presindo.

[6] Fadil, A. (2002). Organisasi dan Administrasi . Kediri: Nasyiin Press.

[7] Gibson, I. M. (2017). Organisasi dan Manajemen. In A. Annas, Interaksi Pengambilan Keputusan dan evalauasi Kebijakan (p. 76). Makasar: Celebes Media Perkasa.

[8] H. Syamsuddin, R. (2006). Sejarah Dakwah. Bandung: Simbiosa Rekatama Media.

[9] Hasanah, S. N. (2021). Dasar-dasar Manajemen Pendidikan. Lamongan: Academia Publication.

[10] Herman. (2013). Sejarah Pesantren di Indonesia. Jurnal Al-Ta'dib 6 No.2, 145-158.

[11] Herujito, Y. M. (2001). Dasar-Dasar Manajemen. Jakarta: PT. Grasindo.

[12] Illahi, M. M. (2006). Manajemen Dakwah. Jakarta: Prenada Media.

[13] Moh. Ali Aziz, M. (2004). Ilmu Dakwah. Jakarta: Prenadamedia Group.

[14] Muhaimin. (2009). Manajemen Pendidikan: Aplikasi Dalam Penyusunan Rencana Pengembangan Sekolah/ Madrasah. Jakarta : PRENADAMEDIA GROUP.

[15] Muhammad Qaddaruddin Abdullah, M. S. (2019). Pengantar Ilmu Dakwah. CV. Penerbit Qiara Media.

[16] Murodi, M. (2013). Dakwah Islam dan Tantangan Masyarakat Quraisy. Jakarta: Kencana PRENADAMEDIA Group.

[17] Qathani, S. B. (1994). Da'wah Islam Da'wah Bijak. Jakarta: Gema Insani Press.

[18] Rahem, Z. (2016). Jejak Inteletual Pendidikan Islam: Generasi Salafiyah dan Khalafiyah . Yogyakarta: Pustaka Ilmu. 
[19] Sadiah, D. (2015). Metode penelitian Dakwah (Pendekatan Kualitatif dan Kuantitatif). Bandung: PT. REMAJA ROSDAKARYA.

[20] Sterrs, R. (2017). Oraganizational Effectiveness (Behavioral View). In A. Dharma, Interaksi Pengambilan Keputusan dan Evaluasi Kebijakan (p. 76). Makasar: Celebes Media Perkasa.

[21] Stoner James, A., \& Charles, W. (1988). Manajemen Jilid 1. In Bakowatun, Manajemen Jilid 1 (p. 126). Jakarta: CV Intemedia.

[22] Suparman. (2019). Kepemimpinan Kepala Sekolah dan Guru (Sebuah Pengantar Teunitik). Uwais Inspirasi Indonesia.

[23] Syamsudin, A. (2016). Pengantar Sosiologi Dakwah. Jakarta: K E N C A N A.

[24] Tajung, D. H. (2003). Manajemen Syariah dalam Praktik. Jakarta: Gema Insani.

[25] Takdir, M. (2018). Modernisasi Kurikulum Pesantren . Yogyakarta: IRCiSoD.

[26] Umar, H. (2005). Evaluasi Kinerja Perusahaan. Jakarta: Pustaka Utama.

[27] Wahid, A. (2010). Menggerakan Tradisi. Yogyakarta: PT.LKiS Printing Cemerlang. 